\title{
АИТЕРАТУРНЫЕ АРХИВЫ
}

DOI 10.15826/izv2.2017.19.2.021

О. А. Коростелев

УДК 82(091) + 821.161.1-94

Институт мировой литературь им. А. М. Горького РАН Москва, Россия

\section{«С “ЛИТНАСЛЕДСТВОМ” У МЕНЯ БЫЛА ПЕРЕПИСКА ДОЛГАЯ» : К ИСТОРИИ НЕСОСТОЯВШЕГОСЯ СОТРУДНИЧЕСТВА Г. В. АДАМОВИЧА В БУНИНСКОМ ТОМЕ*}

Публикация посвящена одной из ранних попыток советских редакций возобновить отношения с эмигрантами в период «оттепели», когда это стало возможным. Эпистолярное общение, а тем более сотрудничество советских изданий с писателями русского зарубежья было в то время исключительно редким явлением. Одним из первых опытов привлечения эмигрантских авторов к сотрудничеству был бунинский том «Литературного наследства», подготовка которого началась в середине 1960-х гг. В процессе подготовки этого тома редакторы «Литературного наследства» в 1966 г. обратились к Г. В. Адамовичу с просьбой написать воспоминания об И. А. Бунине. Его переписка с редакцией продолжалась несколько лет (1966-1970), воспоминания были написаны, однако к тому времени «оттепель» уже закончилась, и редакторам в результате не удалось провести воспоминания через советскую цензуру. Опыт возвращения И. А. Бунина и эмигрантской литературы в Россию в то время удался лишь отчасти. В качестве приложения публикуется вся сохранившаяся переписка Г. В. Адамовича с редакторами бунинского тома, отложившаяся в редакционном архиве «Литературного наследства» и ныне находящаяся в Отделе рукописей Института мировой литературы им. А. М. Горького (ОР ИМЛИ, ф. 575).

К л ю ч е в ы е с л о в а: Г. В. Адамович; И. А. Бунин; А. К. Бабореко; С. А. Макашин; «Литературное наследство»; русская эмиграция; мемуары; «оттепель».

\footnotetext{
* Работа выполнена при финансовой поддержке РФФИ, проект № 15-04-00297а «“Литературное наследство”: научная школа и академическая серия в истории отечественного литературоведения 1930-1980-х гг.».

() Коростелев О. А., 2017
}

Известия УрФУ. Серия 2. Гуманитарные науки. 2017. Т. 19. № 2 (163). С. 9-37 
После 1926 г. эмигранты в советской печати появлялись исключительно редко. К концу 1920-х гг. размежевание русской литературы на две ветви оформилось окончательно и надолго. В глазах советских людей эмигранты предстали врагами, и даже упоминания о них были нежелательны. Такое положение дел продолжалось десятилетия. Поток «возвращенной» литературы хлынул лишь с конца 1980-х гг., но отдельные попытки случались и раньше.

Одним из первых опытов привлечения эмигрантских авторов был бунинский том «Литературного наследства», готовившийся в 1966-1972 гг.

Для редакторов советского издания общение с эмигрантами в то время было делом, мягко говоря, нетипичным и даже смелым, еще совсем недавно за чтение эмигрантской литературы или похвалы ей можно было получить срок. А редакторы «Литературного наследства» не просто вели с ними переписку, но и приглашали к сотрудничеству, причем не одного-двух, а сразу многих авторов. Оттепель уже кончалась, однако редакторы, видимо, этого еще не ощутили.

Первым из эмигрантов, к кому обратилась редакция, был Г. В. Адамович. Автор совсем не академический, далекий от архивно-публикационной работы, на чем специализировалось «Литературное наследство», он хорошо знал И. А. Бунина и был одним из главных эмигрантских критиков.

К литературоведению (даже к самому этому слову) Адамович относился с большой иронией, однако когда доходило до действительно важных работ, тональность его резко менялась. Об издательской серии «Литературное наследство» и людях, которые ее выпускали, он отозвался очень высоко еще в 1952 г.:

Советское «литературоведение» - как теперь выражаются в Москве, - стоит, бесспорно, на большой высоте, если не в той своей части, куда замешалась идеология, то, по крайней мере, в части исторической. Некоторые ценнейшие тома «Литературного наследства», или работы, посвященные Пушкину, или хотя бы такие издания, как собрание писем Достоевского, под редакцией Долинина, с необыкновенно тщательно, толково и богато подобранными примечаниями, свидетельствуют о наличии исследователей, которым каждый беспристрастный человек должен отдать должное [Адамович, 1952, с. 8].

Оценил Адамович и умение «Литнаследства» публиковать авторов, казалось бы, полностью вычеркнутых из советского обихода:

В 1935 году, - т. е. в годы самые суровые, когда от раннего советского литературного либерализма, вдохновлявшегося Луначарским, не осталось и следа, - Леонтьеву был посвящен отдел одного из томов «Литературного наследства» [Адамович, 1957, c. 8].

До войны, когда Адамович подвизался в «Последних новостях», эта тема считалась прерогативой его коллеги по газете Р. Словцова (Н.В.Калишевича), который опубликовал в общей сложности 25 статей о томах «Литературного наследства» [Указатель публикаций, с. 360-369]. Поэтому развернутых печатных отзывов Адамовича того периода не осталось, одни лишь упоминания, но и по ним видно, что он уже тогда относился к «Литнаследству» с пиететом. 
А после войны он откликался и отдельными публикациями, см., например, статью о лермонтовском томе [Адамович, 1949, с. 4].

Поэтому предложение о сотрудничестве именно от «Литературного наследства» Адамович не отклонил сразу, а, хоть и не без сомнений, склонен был принять.

Редакторы и составители тома также надеялись на то, что сотрудничество будет успешным. Гораздо позже, в 1987 г., С. А. Макашин подробно рассказал об этом под магнитофонную запись:

Самые интересные воспоминания (ну, сейчас они появятся, я на этом деле пострадал) - это Георгия Викторовича Адамовича. Это был крупный поэт 20-х годов, акмеист. Он с Гумилевым был дружен. Писатель. У него было плохо с сердцем, и мне Кодрянские... Тоже жил как нищий совершенно... Вообще эти знакомства с этими эмигрантами, за исключением Зайцева, о котором я потом скажу, производили на меня впечатление очень печальное: нищета и голод. Мне Кодрянские сказали, что они хотят меня повести... на Монпарнасе в знаменитую «Ротонду», знаменитое, так сказать, кафе, которое любил Бунин, когда у него были деньги, вот когда он получил Нобелевскую премию, где Маяковский бывал, и там столики, так сказать, знаменитых французских поэтов есть. Но предупредили меня, что больше часа не нужно, чтобы беседа была, потому что Адамович стар и очень устает - и трудно будет.

Но мы разошлись... Мы приехали что-то в восемь часов, в это самое кафе, и уехали только с закрытием, в пять часов утра, потому что он так был увлечен, все спрашивал... Правда, он не москвич, а ленинградец, но Ленинград я все же довольно хорошо знаю... Пушкинский Дом... У него так много друзей там было и всё... Потом я был у него в гостях еще два-три раза. Он охотно согласился написать воспоминания, и написал чудесные воспоминания. Просто они великолепно написаны. Я ему посоветовал не писать ничего (там были политические вещи) о том, как... об этих «Окаянных днях» Бунина, как он, действительно, ненавидел эту самую советскую власть. Я говорю: «Это не пройдет у нас. Оставьте это, так сказать, для будущего». И он написал, собственно, о творчестве, о том, как Бунин писал, Бунин с ним советовался - и всё.

Я привез эти воспоминания. У нас завязалась с ним переписка, очень хорошая, сердечная, она у меня где-то есть, хранится. И потом вдруг он замолчал. Замолчал. Он поздравлял меня всегда с Новым годом. Нет новогоднего поздравления. Я написал Кодрянским, которые знают: «Где Адамович?» Не успел я получить ответ от Кодрянской, как получил письмо, коротенькую открыточку от Адамовича: «Сергей Александрович, дорогой, извините, пожалуйста, что... У меня накопилось несколько ваших писем, я отвечу вам потом. Я только что приехал из Соединенных Штатов, где я читал лекции (это пять-шесть месяцев), сейчас еду к себе в Ниццу (У него была на окраине Ниццы маленькая такая дачка. - Прим. Макашина) и оттуда я вам напишу обо всем, в том числе вы мне скажите о моих воспоминаниях». Ну, и опять молчание. Опять я пишу Кодрянским. Они пишут: «Знаете, произошло несчастье. Как только он приехал в Ниццу, сам, на своей машине, вышел из машины и упал мертвым». В его годы уже это было трудно - поездка в Соединенные Штаты. <...>

Эти воспоминания сейчас... я их привез, я не Зильберштейн, я ничего дома себе не оставляю, не храню. Все, что я привозил из Парижа, я сейчас же передавал в ЦГАЛИ. Там эта рукопись и хранится. Но я показал ее, так сказать, Бабореко, 
и Бабореко попросил у меня 2-3 дня, он снял копию... Ну, была, конечно, копия и у самого Адамовича. Они изданы, эти воспоминания, в Америке.

А сейчас вот я узнал из «Литературной газеты», из беседы с Баклановым, что в «Знамени» будет портрет Бунина Адамовича. Я позвонил Бабореко и говорю: «Что это за портрет такой?» - «А вот это те воспоминания, которые вы прислали, привезли». Я говорю: «Ну, так, во-первых, это не портрет, это все-таки очерк... это как-то... ну, изложение того, как он писал, как он проникает как-то в магию творчества Бунина вот такое, так сказать, это эссе скорее, а не портрет. Но вы, надеюсь, укажете о том, от кого вы получили этот материал? Ведь это я заказывал, я прислал...» Он сказал: «Ну, там сказано, что это должно было печататься в “Литературном наследстве” и не появилось». Я говорю: «Ну, “Литературное наследство” “Литературным наследством”, но все-таки кто-то заказывал, кто-то разговаривал с Адамовичем, по сути дела редактировал...» - «Нет, этого нет. К сожалению, сейчас уже поздно. Уже набрано». Ну, я очень удивился этому, сказал об этом Лакшину. Не знаю, поправят или нет.

Мне это немножко обидно, потому что, действительно, я с Адамовичем работал над этой вещью, потому что там у него были и политические вещи, которые нельзя было печатать, понимаете. Он со мной советовался [Макашин].

Трогательные упоминания о даче в Ницце и собственной машине у Адамовича свидетельствуют только о том, что железный занавес был довольно прочен и сквозь него с трудом просачивались не только конкретные сведения, но даже и самые общие представления о жизни в эмиграции.

Рассказанная Макашиным история гораздо более точно восстанавливается по документам, благо их сохранилось немало.

Сперва к Адамовичу с предложением о сотрудничестве обратился А. К. Бабореко ${ }^{1}$. Адрес он получил от С. Ю. Прегель, с которой был в переписке и которая также была потом приглашена участвовать в бунинском томе «Литературного наследства» [А. Н. Дубовиков - С. Ю. Прегель]. Прегель предварительно поинтересовалась у Адамовича, можно ли дать его адрес, и он ответил ей в письме от 23 мая 1964 г.: «Конечно, Бабореко дать мой адрес можно. Я это имя знаю, но не помню от кого» [С. Ю. Прегель - Г. В. Адамовичу $]^{2}$. У Бабореко с Адамовичем завязалась переписка, продолжавшаяся с 1965 г. по 1971 г. ${ }^{3}$, в ходе которой он и рассказал о готовящемся бунинском томе.

В возможности появления своих воспоминаний в «Литературном наследстве» Адамович сомневался с самого начала и не раз высказывал эти сомнения в письмах. 1 июня 1965 г. он написал А. В. Бахраху:

${ }^{1}$ Александр Кузьмич Бабореко (1913-1999) - литературовед, исследователь творчества Бунина, составитель и комментатор нескольких его изданий, в том числе собрания сочинений, автор биографической книги о нем, впервые опубликованной в 1967 г. Адамович положительно отозвался на эту книгу [Адамович, 1968, c. 4].

${ }^{2}$ В. Крейд дважды опубликовал это письмо, но в обоих случаях вместо фамилии Бабореко указал Бабенко [Письма Георгия Адамовича, 1994б, с. 314; Адамович, 1996, с. 412].

${ }^{3}$ Письма Адамовича Бабореко позже опубликовал [Письма Георгия Адамовича, 1994а]. Встречные письма А. К. Бабореко отложились в бумагах Адамовича в Бахметьевском архиве. 
Мне прислал кучу оттисков и вырезок некий Бабореко, советский «бунинист». Теперь я с ним в переписке. <..> Кстати, они к 1970 году готовят бунинский том «Лит<ературного> наследства» и он просит меня дать статью. Но это едва ли возможно, - не только для меня, но и для него, т. е. если бы я статью и написал, ее едва ли приняло бы его начальство [Письма Георгия Адамовича А. В. Бахраху (1957-1965), c. 178; приводится по оригиналу: BAR. Ms Coll Bacherac].

Бабореко, однако, был настойчив, и 14 октября 1965 г. Адамович написал ему:

Два слова о статье, которую я, по вашему желанию, мог бы дать в юбилейную книгу о Бунине. Вопрос это довольно сложный и надеюсь, вы меня поймете. По существу я, конечно, был бы рад желание ваше исполнить. Даже больше, чем рад: счастлив. Но есть условности, с которыми, к сожалению, приходится считаться. Поэтому, Александр Кузьмич, отложим разговор об этом. А там - видно будет! Кстати, мне хотелось бы знать, от кого исходит ваше предложение: от вас единолично или от всех тех, от кого такое решение зависит? [Письма Георгия Адамовича, 1994a, с. 83].

Тогда Бабореко обратился к одному из редакторов-составителей тома А. Н. Дубовикову с просьбой направить Адамовичу официальное приглашение. Позже, публикуя письма Адамовича к нему, Бабореко написал в примечаниях:

А. Н. Дубовиков занимался редакционной работой по изданию бунинского тома «Литературного наследства» (том 84). Его и члена редколлегии С. А. Макашина нужно было долго убеждать, чтобы согласились послать официальное письмо относительно воспоминаний о Бунине Адамовичу и некоторым другим лицам, например, художнице Т. Д. Логиновой-Муравьевой [Там же, с. 85].

Бабореко тут же принялся торопить Адамовича, а тот, продолжая сомневаться, писал ему 23 августа 1966 г.:

Вы просите «начать писать воспоминания о Бунине сейчас же», не откладывая. Но ведь, если я не ошибаюсь, том «Литературного наследства» приурочен к 1970 году. Значит, спешить как будто нечего, а я смолоду привык писать все чуть ли не в последнюю минуту. Когда приблизительно статья была бы, по вашим расчетам, нужна? Думаю, что если к будущей осени, то и то будет не поздно [Там же, с. 84].

Адамович, еще недавно переживший период покраснения и в 1945-1949 гг. сотрудничавший в просоветской газете «Русские новости», хорошо понимал, что и в эмигрантском сообществе не все одобрили бы публикацию в советской печати.

В разгар холодной войны само участие в советских изданиях могло рассматриваться чуть ли не как преступление против нравственности. Эмигрантов вообще могли обвинить в том, что они до своего отъезда печатались в СССР и таким образом сотрудничали с советской властью, особо ретивые блюстители нравственности считали это несовместимым с высоким званием эмигранта 5 .

\footnotetext{
${ }^{4}$ Тем не менее, 18 мая 1966 г. Дубовиков такое письмо послал (см. п. 1 наст. публ.).

${ }^{5}$ Наиболее ярко это проявилось в полемике вокруг статей Н. И. Ульянова. О «деле Ульянова» и реакции Г. В. Адамовича на него см.: [«Если чудо вообще возможно за границей...», с. 306-307].
} 
Размышляя о том, какой может быть реакция эмигрантского общественного мнения на подобное сотрудничество, Адамович 25 октября 1966 г. написал М. В. Вишняку:

С год тому назад ко мне обратился из Москвы некий Бабореко, член редакционной коллегии «Литер<атурного> наследства», с просьбой написать статью о Бунине. К столетию со дня его рождения, в 1970 году, они выпускают целый том, полностью Бунину посвященный.

Я ответил уклончиво, и с тех пор переписка моя с Бабореко длится. По письмам он человек приятный, исключительно вежливый и даже почтительный. Получил я письмо и от другого, более ответственного сотрудника «Лит<ературного> наследства» с той же просьбой.

В конце концов я ответил: «Да, хорошо, напишу, но при одном условии: ни одного слова не изменять, ни слова не добавлять от себя». Они немедленно согласились.

Вот, Марк Веньяминович, я и хочу Вас спросить: что Вы об этом деле думаете? Общественного опыта у Вас много больше, чем у меня. Не сомневаюсь, что если бы в «Лит<ературном> н<аследстве>» статья моя появилась, кое-кто в эмиграции поднял бы крик и вопль, - например, Ульянов. Но лично я не вижу причин отказываться, да кроме того для меня было бы радостью написать, наконец, что-нибудь для 100000 читателей, а не для 5-10, как здесь. «Лит<ературное> наследство» - орган солидный, и хотя, конечно, над ним есть тот же присмотр, как и над другими советскими изданиями, чувствуется это гораздо меньше. Если бы я статью туда послал, то предварительно сделал бы фотокопию и с рукописи, и с сопроводительного письма.

Буду Вам очень благодарен за ответ, но очень прошу Вас никому об этом моем письме к Вам не говорить [«Не будьте на меня в претензии...», с. 431-432].

М. В. Вишняк ответил положительно, что, однако, всех сомнений Адамовича не разрешило. Позже он излагал их в письме В. Д. Самарину 29 августа 1969 г.:

Кажется, я Вам говорил о своей долгой переписке с редакцией московского «Лит. наследства», готовящего к 1970 году бунинский том. В конце концов, после колебаний и сомнений, я послал им довольно длинные воспоминания о Бунине. Ответ был до крайности любезный, со всяческими комплиментами. Но теперь, в связи с очередным «зажимом», я далеко не уверен, что им разрешат поместить что-либо за подписью эмигранта. Должно там быть еще что-то Галины Кузнецовой и Бахраха. Но редактора «Л<итературного > н<аследства >» - люди подневольные, и едва ли все это появится, несмотря на их горячее желание. Если не появится, я, конечно, помещу свои записки в одном из здешних изданий.

\footnotetext{
${ }^{6}$ Владимир Самарин (наст. имя: Владимир Дмитриевич Соколов; 1913-1992) - учитель литературы в Воронеже, журналист, в 1942 г. оказался в оккупации в Орле, печатался в оккупационных газетах «Речь» и «Воля народа», после войны провел несколько лет в Германии в лагерях для перемещенных лиц, был членом НТС, редактором «Пути» (1946-1949) и «Посева» (1949-1951). В 1951 г. перебрался в США, работал в издательстве имени Чехова, сотрудничал с «Гранями», «Возрождением», «Русской мыслью», опубликовал несколько книг прозы; с 1959 г. преподавал русский язык в Йельском университете. После того, как в 1976 г. в «Sowjetisches Heimland» появилась информация о его коллаборационизме во время войны, вынужден был оставить преподавание и уехал в Канаду. Письма Адамовича Самарину 1965-1972 гг. хранятся в Beineke Rare Book and Manuscript Library (Yale University).
} 
Повторяю, у меня были долгие колебания: как никак, «Лит<ературное> н<аследство $>$ - издание все-таки советское. Знаю, что Андрей Седых от участия отказался. Вероятно, будут нарекания. Но такие «столпы» антикоммунизма, как, например, М. В. Вишняк, считают, что отказываться не следовало - и я с этим согласен. Имеет ведь значение и то, что здесь читает 1000 человек, а там 100 000, даже больше, - причем здесь «почитывают», а там читают с жадностью, в особенности все о Бунине [Г. В. Адамович - В. Д. Самарину].

Ответ на свое июньское послание Дубовикову Адамович получил только в декабре и написал Бабореко 2 января 1967 г.:

Письмо из редакции «Литературного наследства» я получил. Сегодня отвечу А. Н. Дубовикову. Вы просите меня «начать писать статью о Бунине немедленно». Но ведь нужна она вам к осени! Я все всегда пишу в последний срок, так что если примусь за статью летом, времени у меня будет более чем достаточно [Письма Георгия Адамовича, 1994a, с. 85].

Несмотря на то, что Адамович всячески откладывал написание воспоминаний по свойственной ему привычке сдавать материалы в последний момент, и несмотря на все сомнения в возможности публикации, он твердо решился написать их, более того, подталкивал к сотрудничеству в «Литературном наследстве» своих знакомых: А. В. Бахраха, Н. В. Кодрянскую.

2 января 1969 г. Адамович написал Бахраху:

«Лит<ературное> наследство». Вы правы: сокращения на крайнюю крайность допустимы. Но изменения ни в коем случае. Я это им писал дважды, а ответ был неясный: «да, конечно...» и какая-то канитель дальше. <...> Все же я обещал, - как, кажется, писал Вам уже - прислать конец воспоминаний в феврале, из Ниццы, куда собираюсь недели через 2 1ㄹ. Во всяком случае, Вы будете в «Л<итературном> н<аследстве>» не в одиночестве, т. к. что-то послал им д-р Зернов, притом не только медицинское. Но, верно, буду и я, т. е. пошлю им, а там видно будет. Я очень сомневаюсь в появлении наших произведений [Письма Георгия Адамовича А. В. Бахраху (1969-1972), с. 132; приводится по оригиналу: BAR. Ms Coll Bacherac].

Несколько месяцев спустя, 25 августа 1970 г. Адамович из Ниццы писал Н. В. Кодрянской, собиравшейся нанести визит в СССР:

Очень рад, что Вы отослали в Москву Вашу рукопись и надеюсь, редакция «Лит<ературного> наследства» успеет ее включить в бунинский том. Недели две-три назад я получил письмо от А. Н. Дубовикова (со-редактора, вместе с Макашиным, этого тома), который сообщил, что весь полученный до сих пор матерьял прошел две цензурные инстанции без препятствий. А в Париже были другие слухи, не знаю, верные ли. В Москве Вы, верно, узнаете, как действительно обстоит дело [Г. В. Адамович - Н. В. Кодрянской].

Подготовка бунинского тома «Литнаследства» сильно затянулась, и к столетию он не вышел. 
31 мая 1971 г. Адамович написал А. К. Бабореко:

По моим догадкам и смутным предчувствиям дело с моими воспоминаниями о Бунине обстоит скорее плохо, да и вообще выход этого тома задерживается на неопределенный срок. Мне это досадно, так как я хотел бы знать, могу ли я использовать свои записки иначе. Ну, поживем - увидим [Письма Георгия Адамовича, 1994a, c. 87].

До выхода бунинского тома Адамович не дожил, том в результате был выпущен тремя годами позже назначенного срока [Литературное наследство, т. 84]. «Воспоминания» в него не вошли, хотя именно в этом томе был напечатан отзыв Бунина об Адамовиче: «Лучший критик в эмиграции, в Париже» [Там же, с. 679].

После того, как выяснилось, что редакция «Литературного наследства» не может обнародовать заказанные мемуары, Адамович напечатал их в НьюЙорке [Адамович, 1971]. В России их впервые издал А. К. Бабореко 17 лет спустя [Адамович, 1988].

Ниже публикуется вся сохранившая переписка Г. В. Адамовича с редакторами бунинского тома, отложившаяся в редакционном архиве «Литературного наследства» (ныне в ОР ИМЛИ, ф. 575). Несколько писем С. А. Макашин посылал с домашнего адреса, они не сохранились, поскольку копий в редакционном архиве не осталось, а Адамович приходящие к нему письма и вовсе не сохранял за редкими исключениями. Об одном из них Адамович упоминает в письме Бахраху от 12 янв<аря > 1970 г.:

Да, после долгого молчания (1/2 года!) пришло письмо от Макашина, из «Лит<ературного> наследства». Поздравление с упоминанием, что «бунинский том медленно подвигается». Я писал Бабореке о своих сомнениях насчет возможности, т. е. приемлемости моего участия. М. б., это был завуалированный ответ. Скажите, известно Вам, кто там предположен из эмигрантов? Вы, Галина - а еще? Мне хотелось бы, чтобы было побольше. Я написал такому Самарину (Yale University), что послал в Москву свои воспоминания о Б<унине > и получил в ответ долгий вздох: «как, зачем?» и т. д. Впрочем, через две недели он сообщил, что долго думал и решил, что я прав, - главным образом согласившись с моим доводом, что тут читает 100 человек, а там 100 000. А если на меня обрушится Гуль с Глебом Струве, то это мне все равно. Думаю, Вам тоже [Письма Георгия Адамовича А. В. Бахраху (1969-1972), с. 144; приводится по оригиналу: BAR. Ms Coll Bacherac].

Уже после смерти Адамовича и после выхода бунинского тома А. Н. Дубовиков в письме А. В. Бахраху от 1 октября 1973 г. объяснял причину невключения воспоминаний превышением объема:

К сожалению, нам не удалось напечатать в томе Ваши воспоминания о Бунине. Когда закончилось составление тома и было подсчитано количество листов в нем, оказалось, что мы намного превысили объем, предусмотренный планом издательства. Нам пришлось сократить том на несколько десятков листов, пожертвовав при этом рядом весьма ценных материалов. В числе их оказались и Ваши воспоминания [А. Н. Дубовиков - А. В. Бахраху]. 
С. А. Макашин в своих записанных на магнитофон воспоминаниях назвал совсем другую причину:

Когда я включил эти воспоминания в этот бунинский том, Главлит их снял. Ну, я пошел туда выяснять. Мне объяснили причину. Оказывается, он читал лекции в Америке о Солженицыне. И вот это... И хотя там, в этих воспоминаниях, абсолютно никакой антисоветчины не было, ничего, но за то, что он читал в Америке о Солженицыне - сняли [Макашин].

Специальных лекций о Солженицыне Адамович в США не читал, но мог упоминать о нем, выступая в американских университетах - Йельском, НьюЙоркском, Джорджтаунском (Вашингтон), Гарвардском (Бостон), Колумбийском (Нью-Йорк). А вот публикации о Солженицыне у него были, и немало, причем еще до поездки в США и даже задолго до начала переписки с редакцией «Литературного наследства» ${ }^{7}$. Были также беседы с Виктором Франком на Радио «Свобода», тексты которых напечатаны посмертно ${ }^{8}$. Думается, реальной причиной как раз и могло быть сотрудничество с радиостанцией «Свобода», где А. В. Бахрах возглавлял отдел, а Адамович был одним из постоянных авторов 9 .

31 января 1974 г. научный сотрудник «Литературного наследства» Т. Г. Динесман передала в ЦГАЛИ, среди прочего, материалы бунинского 84 тома, в том числе копии 17 писем Бунина 1944-1945 гг. и машинопись воспоминаний Адамовича с пометой: «Написаны для “Лит. наследства”. Машинопись с авторской правкой 20 л. В том “Лит. наследства” не вошло» [Акт].

В том, кроме того, не вошли готовившиеся для него воспоминания А. В. Бахpaха, И. В. Одоевцевой, Г. Н. Кузнецовой, а воспоминания Т. Д. Муравьевой вошли с сокращениями. Из «Грасского дневника» Г. Н. Кузнецовой были напечатаны только фрагменты. Фотографии, полученные от Л. Ф. Зурова из парижского архива И. А. Бунина, также были использованы в томе лишь частично.

Однако и включенных в том материалов оказалось достаточно, чтобы российские читатели сочли его одним из главных событий в возвращении эмигрантского Бунина.

${ }^{7}$ Вот лишь самые основные:

Адамович Г. В. Литература и жизнь // Русская мысль. 1963. 3 января. № 1938. С. 1. [«Один день Ивана Денисовича»].

Адамович Г. В. Литература и жизнь // Русская мысль. 1963. 21 сентября. № 2050. С. 1. [«Для пользы дела»].

Адамович Г. В. «Раковый корпус»: Повесть Александра Солженицына // Русская мысль. 1968. 23 мая. № 2687. С. 3; то же: Новое русское слово. 1968. 25 августа.

Адамович Г. В. Солженицын // Русская мысль. 1969. 20 марта. № 2730. Приложение. С. I.

Адамович Г. В. Солженицын - Нобелевский лауреат // Русская мысль. 1970. 15 октября. № 2812. С. 1. Адамович Г. В. Нобелевская премия // Русская мысль. 1970. 10 декабря. № 2820. С. 1.

Адамович Г. В. «Август четырнадцатого». Роман Солженицына // Русская мысль. 1971. 24 июня. № 2848.

C. 1; то же под названием: Новый роман Солженицына // Новое русское слово. 1971. 4 июля. С. 8.

${ }^{8}$ Адамович Г. В. Место Солженицына в русской литературе // Русская мысль. 1974. 4 апреля. № 2993.

С. 7; Георгий Адамович о Солженицыне // Русская мысль. 1980. 10 апреля. № 3303. С. 11, 14.

${ }^{9}$ Из его скриптов, написанных для радиостанции, опубликована лишь малая часть: [Адамович, 1967]. 


\section{1. А. Н. Дубовиков - Г. В. Адамовичу ${ }^{10}$ \\ 18 мая 1966 г. Москва}

18 мая 1966 г.

Уважаемый Георгий Викторович!

Редакция «Литературного наследства» приступила в настоящее время к подготовке тома, посвященного И. А. Бунину. Этот том предполагается выпустить в свет к 100-летию со дня рождения писателя, в 1970 году.

От одного из основных участников тома, А. К. Бабореко, нам стало известно, что Вы собираетесь писать воспоминания о Бунине. Мы охотно обсудили бы в редколлегии нашего издания вопрос о включении Ваших воспоминаний в бунинский том, но для этого нам необходимо располагать некоторыми предварительными сведениями о задуманных Вами мемуарах.

Если Вы в принципе не возражаете против участия в названном томе, будьте добры, известите нас об этом и пришлите краткий проспект. Желательно, чтобы в нем был указан приблизительный объем воспоминаний, срок, когда они могут быть готовы, какой период жизни Бунина будет ими охвачен, какие творческие и биографические темы могут быть в них освещены. Нам будет также интересно знать, какие документальные материалы (письма, дневниковые записи, свидетельства некоторых лиц и т. п.) будут положены в основу Ваших воспоминаний ${ }^{11}$.

После рассмотрения Вашего проспекта на заседании редколлегии мы сообщим Вам о состоявшемся решении и вышлем Вам официальное приглашение участвовать в томе.

Член редколлегии «Литературного наследства» (А. Н. Дубовиков)

\footnotetext{
${ }^{10}$ Печатается по оригиналу (отпуск машинописи с исходящим номером «№ 118» и пометой от руки вверху письма: «Г. В. Адамовичу. Париж»).

1119 июня 1966 г. Адамович сообщал А. В. Бахраху:

Не помню, писал ли я Вам о «Лит<ературном> наследстве». Этот Бабореко уже давно убеждал меня написать туда о Бунине. Я отвечал уклончиво, а главное - просил «уточнить»: кто меня об этом просит, сам ли Бабореко, мелкая сошка, или ихнее начальство? Недели две назад я получил предложение официальное, на бланке, от «члена редколлегии». Но не без хамства! Смысл такой: мы слышали, что Вы собираетесь писать о Б<унине>, это могло бы нам подойти, но сообщите нам, какие Вы используете матерьялы, документы и т. п. Тогда мы известим Вас о своем решении. Подпись без всякой formule de politesse.

Я ответил в том же духе. Ничего не «собирался», просил меня об этом Ваш же сотрудник, никаких «матерьялов» я не использую, а могу написать просто воспоминания о встречах и беседах.

Ответа до сих пор нет. Сообщаю я Вам об этом потому, что Вы с Бабореко в переписке. Кстати, этот Бабореко просил меня «не обращать внимания» на характер официального письма и на всякие вопросы. «Иначе, мол, у нас нельзя». Но, по-моему, Вы тоже должны потребовать, чтобы к Вам обратилась инстанция повыше его. Если я получу ответ приемлемый, то поставлю условием: ничего не изменять и не добавлять, дав им понять, что, конечно, политики я касаться не буду. Но непременно напишу, что Б<унин $>$ в эмиграции не выдохся, а расцвел. У меня был об этом осенью разговор с Твардовским: он - страстный поклонник Б<унина>, но тоже уверял, что здесь он выдохся, как я его ни уверял, что это чепуха [Письма Георгия Адамовича А. В. Бахраху (1966-1968), с. 157; приводится по оригиналу: BAR. Ms Coll Bacherac].
} 


\section{2. Г. В. Адамович - А. Н. Дубовикову ${ }^{12}$ \\ 4 июня 1966 г. Париж}

Paris 8

7 , rue Fréd<éric $>$ Bastiat 4 июня 1966

Многоуважаемый Алексей Николаевич

Благодарю Вас за письмо.

Правду сказать, мысли писать воспоминания о Бунине у меня до сих пор не было. Принадлежит эта мысль А. К. Бабореко. Но ничего против нее я не имею.

Должен, однако, Вас предупредить, что никакими «документальными материалами» - Ваше выражение - пользоваться я не стал бы. У всякого пишущего свой стиль, своя манера, а я вовсе не литературовед в обычном смысле этого понятия. Могу я написать непринужденный и по мере своих сил живой рассказ о частых встречах и разговорах с Буниным за последние двадцать пять лет его жизни. Может быть, использую некоторые его письма, хотя очень немногие ${ }^{13}$. Сохранились у меня некоторые записи о беседах с ним. Само собой разумеется, что привел бы я из них только то, что затрагивает темы чисто литературные или, так сказать, общежитейские.

Но основным останется впечатление о человеке, - необыкновенно своеобразном и даровитом, при всем, что в его суждениях было спорного, - которого я наблюдал долго и пристально.

Подходит это Вам или нет, решать не мне.

С приветом

Георгий Адамович

\section{3. А. Н. Дубовиков - Г. В. Адамовичу ${ }^{14}$ 13-15 декабря 1966 г. Москва}

13/15 декабря 1966 г.

Многоуважаемый Георгий Викторович!

Мы давно получили Ваше июньское письмо, но, к нашему большому сожалению, не смогли сразу ответить на него. Оно пришло в период летних отпусков, когда редколлегия прервала свою работу; а когда лето кончилось, мы были вынуждены на время отложить бунинские планы и заняться более срочными делами - главным образом, 78-м томом («Советские писатели на фронтах Великой Отечественной войны» ${ }^{15}$ ), который теперь уже вышел в свет. Сейчас мы вернулись к Бунину и вплотную приступили к подготовке посвященного ему тома. Наши предложения о характере будущего тома и о круге приглашаемых к участию в нем авторов ${ }^{16}$ получили поддержку со стороны редколлегии.

\footnotetext{
12 Печатается по оригиналу (машинопись с подписью-автографом и вписанным от руки адресом).

${ }^{13}$ Адамович к тому времени уже публиковал фрагменты писем И. А. Бунина к нему [Бунин, 1956]. Еще одна подборка вышла посмертно: [Письма И. А. Бунина к Г. В. Адамовичу].

${ }^{14}$ Печатается по оригиналу (отпуск машинописи с исходящим номером «№ 228» и пометой от руки вверху письма: «Адамович»; также от руки добавлен слэш и 15 число к машинописной дате «13 декабря»).

${ }^{15}$ Имеется в виду очередной том серии, вышедший в двух книгах [Литературное наследство, т. 78].

${ }^{16}$ K бунинскому тому редакция «Литературного наследства» пыталась привлечь всех, кто мог знать И. А. Бунина и написать о нем, и вступила в переписку по этому поводу с десятками авторов: от И. С. Соколова-Микитова и К. И. Чуковского до К. М. Симонова и Ю. П. Казакова.
} 
То, что Вы написали о содержании Ваших воспоминаний и об их литературной форме, не вызывает у нас никаких возражений, и мы просим рассматривать настоящее письмо как официальное приглашение участвовать в томе, посвященном Бунину. Мы хотели бы получить Ваши воспоминания не позднее лета или осени 1967 года, потому что нам необходимо к началу 1968 г. закончить составление тома и редактирование его.

Разумеется, Ваш труд будет оплачен по обычным для нашего издания нормам. Но я должен предупредить Вас, что ни редакция «Литературного наследства», ни издательство «Наука», которое выпускает наши тома, не располагают возможностями для перевода гонорара за границу в иностранной валюте. Следуемая Вам сумма будет выплачена (после выхода тома из печати) советскими деньгами - Вам или по Вашей доверенности другому лицу, которое приедет в СССР или постоянно живет здесь. В случае Вашего желания, редакция может также выслать в счет гонорара интересующие Вас книги, изданные в Советском Союзе.

Будьте добры, сообщите, что́ Вы могли бы прислать нам (в фотокопиях) для иллюстрирования тома. Вероятно, у Вас есть портреты Бунина с его дарственными надписями, его книги с автографами, фотографии мест, где он жил и т. п. Этим Вы окажете редакции ценную помощь.

С искренним уважением

(А. Н. Дубовиков)

\section{4. Г. В. Адамович - А. Н. Дубовикову ${ }^{17}$ \\ 2 января 1967 2. Париж}

Paris $8^{\mathrm{e}}$

7 , rue Fréd<éric $>$ Bastiat

2 января 1967

Многоуважаемый Алексей Николаевич

Получил Ваше письмо от 13-го декабря.

Если ничего не случится непредвиденного, пришлю воспоминания о Бунине к осени, - как Вы и предлагаете. Фотографий его у меня нет. Может быть, и были, но мелкие, любительские, и я не могу их найти. Некоторые его письма я, вероятно, приведу в статье. Надписи на книгах Ив<ан> Ал<ексееви>ч большей частью делал шутливые. Одна из них так понравилась Н. В. Кодрянской, что она в фотокопии послала ее в Москву, - не знаю точно, куда и кому. На «Темных аллеях» Бунин написал:

«Дорогому Г. В. А. с подобострастием.

Автор. 30.XI.46».

Типично бунинский юмор.

На экземпляре «Речного трактира» (отдельное издание) надпись

«Поэту А. трактирщик Бунин».

Объясняется это тем, что на обложке имя автора стоит как на трактирной вывеске ${ }^{18}$.

${ }^{17}$ Печатается по оригиналу (в верхнем левом углу письма помета другой рукой, по-видимому, при архивировании в редакции: «Вх. № 11. 30.ІІІ-67 г.»).

${ }^{18}$ Обложку книги оформлял М. В. Добужинский, украсив ее в качестве виньетки изображением гармони: [Бунин, 1945]. 
Если Вас подобные мелочи интересуют, я могу сделать фотокопию. Может быть, найду и что-нибудь другое, порывшись в своем «архиве», который находится в состоянии хаотическом.

Вопрос о гонораре значения не имеет. Если Вы в свое время пришлете мне некоторые интересующие меня книги, я буду вполне удовлетворен.

С искренним приветом

Георгий Адамович

\section{5. А. Н. Дубовиков - Г. В. Адамовичу ${ }^{19}$ \\ 23 декабря 1967 2. Москва}

23 декабря 1967 г.

Глубокоуважаемый Георгий Викторович!

Я давно не писал Вам, все надеялся, что придут Ваши воспоминания о Бунине. Но вот подошел Новый год, а их все нет...

Будьте добры, напишите, когда Вы предполагаете закончить эту работу и прислать ее в «Литературное наследство». Мы хотим завершить работу по собиранию материалов для бунинского тома к концу февраля. Было бы очень хорошо, чтобы и Ваши воспоминания поспели к этому времени.

Поздравляю Вас с наступающим Новым годом и желаю Вам всего доброго.

С искренним уважением

(А. Н. Дубовиков)

\section{6. Г. В. Адамович - А. Н. Дубовикову ${ }^{20}$ \\ 3 января 1968 г. Париж}

Paris 8

7 , rue Fréd $<$ éric $>$ Bastiat

3 января 1968

Глубокоуважаемый Алексей Николаевич

Получил Ваше письмо от 23-го декабря.

Должен признаться, я не знал, - или забыл, - что собирание матерьяла для бунинского тома «Лит. наследства» Вы хотели бы закончить в феврале. К сожалению, я сейчас очень занят, да к тому же и не совсем здоров. К концу февраля написать свои воспоминания я не успею. Не будет ли слишком поздно, если я пришлю их Вам, скажем, к концу апреля?

Обещаю, в случае Вашего согласия, быть аккуратным в соблюдении срока. Но мне нужно было бы знать, что согласие Вы даете.

Искренне благодарю Вас за пожелания к Новому году и в свою очередь желаю Вам здоровья и благополучия.

С искренним уважением

Георгий Адамович

\footnotetext{
${ }^{19}$ Печатается по оригиналу (отпуск машинописи с пометами от руки «Исх. № 164» и «Адамовичу»).

${ }^{20}$ Печатается по оригиналу (в верхнем левом углу письма помета другой рукой: «Вх. № 5. 19.I.68 г.»).
} 


\section{7. А. Н. Дубовиков - Г. В. Адамовичу ${ }^{21}$ 19 января 1968 г. Москва}

19 января 1968 г.

Глубокоуважаемый Георгий Викторович!

Ваше письмо, признаться, огорчило нас, так как мы рассчитывали на скорое уже получение Ваших воспоминаний о Бунине. Но что поделать! Деваться нам некуда, отказываться от Ваших воспоминаний нам очень не хочется, поэтому не остается ничего иного, как согласиться на конец апреля ${ }^{22}$. Но при этом мы все-таки просим Вас по возможности приблизить назначенный Вами срок хотя бы на неделю-другую. При напряженных темпах работы над томом это облегчит наше положение.

На мой вопрос насчет Ваших старых статей о Бунине Вы мне ничего не ответили. Если не трудно, напишите, пожалуйста, можем ли мы рассчитывать на Вашу помощь в этом деле.

С искренним уважением

(А. Н. Дубовиков)

\section{8. Г. В. Адамович - А. Н. Дубовикову ${ }^{23}$ \\ 15 апреля 1968 г. Париж}

Paris $8^{\mathrm{e}}$

7 , rue Fréd $<$ éric $>$ Bastiat

15 апреля 1968

Глубокоуважаемый Алексей Николаевич

Я был нездоров и потому принялся за статью о Бунине только совсем недавно. Предполагал послать ее Вам полностью к концу месяца, как и обещал. Но потом передумал, и вот почему.

Впервые, после долгих лет, я пишу для советского издания. Прекрасно понимаю, что у Вас могут возникнуть какие-нибудь возражения или замечания. «Ум хорошо, а два лучше», и в данном случае это вернее, чем когда-либо.

Надеюсь, однако, - и даже уверен, - что и Вы понимаете, что никаких правок, изменений и сокращений, сделанных помимо меня и без моего ведома и согласия, допустить я не могу. Поэтому я и посылаю Вам только первую половину этих моих воспоминаний: если Вы признаете, что в них все в порядке, - или предложите мне некоторые незначительные изменения, для меня приемлемые, - я допишу и вышлю Вам вторую часть (приблизительно такого же размера) в самые ближайшие дни.

Буду, однако, ждать Вашего ответа, чтобы поступить в соответствии с его содержанием.

${ }^{21}$ Печатается по оригиналу (отпуск машинописи с исходящим номером «№ 20» и пометой от руки: «Адамовичу»).

225 марта 1968 г. Адамович писал Бахраху:

«Лит<ературное> наследство». Они месяца полтора назад прислали мне запрос: где обещанная

статья? Февраль будто бы - последний срок. Я ответил, что о прыгать не может быть речи, и предложил конец апреля. Пожалуйста, напишите статью тоже. На конец апреля они (Дубовиков) согласились, хотя и без удовольствия. Мне было бы неприятно быть в «Л<итературном> н<аследстве>» одному из всех эмигрантов. Впрочем, Софочка $<$ Прегель $>$, кажется, что-то сочиняет и им пошлет [Письма Георгия Адамовича А. В. Бахраху (1966-1968), с. 182; приводится по оригиналу: BAR. Ms Coll Bacherac].

${ }^{23}$ Печатается по оригиналу (машинопись с подписью-автографом и вписанными от руки адресом и датой. Вверху письма помета другой рукой: «Вх. № 24. 23.V.68 г.»). 
Прошу простить за задержку и принять, глубокоуважаемый Алексей Николаевич, мои лучшие пожелания.

Георгий Адамович

\section{9. А. Н. Дубовиков - Г. В. Адамовичу ${ }^{24}$ \\ 20 мая 1968 г. Москва}

20 мая 1968 г.

Глубокоуважаемый Георгий Викторович!

Первую часть Ваших воспоминаний о Бунине мы получили своевременно ${ }^{25}$. После меня их прочитал С. А. Макашин (мы с ним вместе готовим бунинский том), а потом с ними познакомились и другие наши коллеги по редакции. Так что последующие строки выражают не только мое личное мнение - это единодушное мнение редакции.

Ваши воспоминания написаны превосходно, читаются они с неослабевающим интересом. Для «Литературного наследства» они особенно ценны тем, что Вы поставили во главу угла не мелкожитейские, бытовые детали, характеризующие Бунина, так сказать, с внешней стороны. У Вас получились литературные воспоминания в подлинном смысле этого слова. Привлекает нас и то, что Ваши воспоминания аналитичны. Воскрешая черты личности Бунина-писателя, Вы размышляете о них и помогаете читателю глубже понять Бунина с его литературными вкусами, симпатиями и антипатиями, с его взглядами на сущность писательского труда. Мне лично показались особенно удачными тонкие замечания об уме Бунина, о присущем ему «чутье к притворству, к фальши», о его отношении к Достоевскому и Толстому (о последнем писалось уже не раз, но Вам удалось сказать об этом как-то очень свежо).

Итак, глубокоуважаемый Георгий Викторович, мы ждем с нетерпением окончания Ваших воспоминаний. Не сомневаемся, что вторая их часть будет не менее интересна, чем первая.

Теперь по поводу Ваших сомнений о возможном вторжении редакторской руки в Ваш текст. Я понимаю, что те формы обращения с авторским текстом, которые приняты во многих современных редакциях, могли возбудить у Вас такие сомнения. Но мы в этом

${ }^{24}$ Печатается по оригиналу (отпуск машинописи с исходящим номером «№ 74» и пометой от руки: «Адамович»).

25 Зато Адамович из-за забастовки получил это письмо с месячным опозданием и, не дождавшись своевременно ответа, написал Бахраху 17 июня 1968 г.:

Отвечаю на Ваши сомнения о «Лит<ературном> наследстве». Я твердо обещал им прислать свой труд к концу апреля - и потому начал писать. Но, поразмыслив, решил, что ввиду тамошнего нажима они могут отказаться от желания украсить этот том эмигрантами. Приблизительно 2 месяца тому назад я послал Дубовикову первую часть своих воспоминаний (страниц 12) <..> Ответа до сих пор нет. Конечно, были забастовки, но письма оттуда уже приходят. Признаюсь, я был бы очень рад, если бы они ответили отказом или вообще не ответили бы. На днях я тут видел одного писателя из Москвы, который обещал мне справиться, как обстоит дело. Но если они ответят «да, согласны», rien à faire $<$ ничего не поделаешь - $p$. $>$, придется сдержать данное обещание. Приятно то, что они дают Вам срок до конца июля. Значит, дадут и мне. А то надо было бы спешить, т. к. в феврале Дубовиков писал мне, что последний срок - конец апреля. Если будут оттуда новости, я Вам сейчас же напишу. Но был бы крайне рад, чтобы и Вы там фигурировали. <...> Мой москвич считает, что Дубовиков не ответил до сих пор потому, что он - пешка и должен, прежде чем ответить «да» или «нет», запросить высшее начальство и даже показать начальству те 12 страниц, которые я ему послал [Письма Георгия Адамовича А. В. Бахраху (1966-1968), с. 183; приводится по оригиналу: BAR. Ms Coll Bacherac]. 
отношении придерживаемся более традиционных методов редакторской работы - без согласования с автором мы никогда не вносим в текст никаких изменений. Естественно, что точно так же мы предполагаем работать и с Вашими воспоминаниями. К тому же мы обязательно посылаем на авторскую корректуру гранки, что дает возможность автору еще раз проверить точность его текста.

О первой части могу сказать, что мы не обнаружили в ней ни одного места, которое следовало бы исключить или переработать, и это нас радует. Редакторская правка (не считая обычных мелочей корректорского порядка) выразится, очевидно, в двух-трех стилистических исправлениях - заранее прошу за это прощения у Вас - опытного писателя и отличного стилиста.

И еще одна мелочь (не стилистическая). Очень выразительно воспроизведя рассказ Бунина об академике, Вы, как нам кажется, не вполне убедительно истолковываете слова последнего: «Крылова... баснописца... хоронили» (стр. 6, внизу). Вряд ли академик мог забыть, что Крылов писал басни; вернее всего, что он запнулся, спохватившись, что для молодого коллеги надо пояснить, о каком именно Крылове идет речь (был, напр., проф. римского права, цензор Н. И. Крылов, он умер в 1879 г; был еще А. Л. Крылов, профессор статистики и тоже цензор, умер в 1853 г. - в академических и литературных кругах оба они были достаточно известны). Не найдете ли Вы возможным дать другую концовку этому эпизоду или снять последние три строки. Что Вы думаете об этом?

Я думаю, что на дальнейшее можно наметить такой план: после получения второй части мы перепечатываем весь текст с желательными на наш взгляд исправлениями и один экземпляр посылаем Вам для утверждения. Здесь же я укажу, какие места потребуют пояснительных примечаний, - их можно будет дать от редакции или от Вашего имени, как Вы захотите.

Заканчивая это затянувшееся письмо, хочу напомнить о Вашем обещании прислать фото книг Бунина с дарственными надписями и еще что-нибудь для иллюстрирования Ваших воспоминаний (Вы собирались порыться в архиве!).

Желаю Вам всего доброго.

С искренним уважением

(А. Н. Дубовиков)

10. Г. В. Адамович - А. Н. Дубовикову ${ }^{26}$

23 июня 1968 г. Париж

Paris 8-e

7, rue Fréd<éric $>$ Bastiat

23 июня 1968

Глубокоуважаемый Алексей Николаевич

Благодарю Вас за письмо.

Я только третьего дня получил его, а написано оно 20-го мая! Причина, конечно, в здешних забастовках, о которых Вы, вероятно, знаете.

Рад, что первую часть моих воспоминаний о Бунине вы одобрили. Надеюсь, что не вызовет у Вас другого отношения и вторая, последняя часть. Но с высылкой ее произойдет некоторая задержка. Дело в том, что я на будущей неделе уезжаю на каникулы и хочу

${ }^{26}$ Печатается по оригиналу (вверху письма помета другой рукой: «Вх. № 42. 2.IX.68 г.»). 
от всех писаний отдохнуть. Мне сообщил А. В. Бахрах, что Вы дали ему срок: август 27. Кажется, и Г. Н. Кузнецова раньше августа ничего Вам не пошлет. Так что будьте добры, подождите и моей присылки до августа. К 15-му августа воспоминания мои во всяком случае будут у Вас («если буду жив», как писал Толстой)

Насчет слов о «Крылове... баснописце», спорить не буду, - хотя и предпочел бы, чтобы Вы оставили мой текст таким, как он есть. Но если Вы считаете последние строки неудачными, выбросьте их (начиная со слов «Как знать, в самом деле?»).

Шлю сердечный привет и лучшие пожелания.

С искренним уважением

Георгий Адамович

P. S. Мой парижский адрес всегда действителен, где бы я ни находился.

\section{1. С. А. Макашин - Г. В. Адамовичу ${ }^{28}$ 20 сентября 1968 г. Москва}

20 сентября 1968 г.

Глубокоуважаемый Георгий Викторович!

К Вам обращается соредактор А. Н. Дубовикова по «бунинскому тому» «Литературного наследства» Сергей Александрович Макашин.

А. К. Бабореко, один из главных участников нашего «бунинского тома», сообщил мне, что Вы поделились с ним своими сомнениями относительно целесообразности продолжать начатые Вами, по нашей просьбе, воспоминания о Бунине, так как опасаетесь, что это уже будет поздно ${ }^{29}$.

А. Н. Дубовиков сейчас отдыхает на Кавказском побережье, и я спешу вместо него сообщить Вам, что время для окончания Вашей работы еще имеется и что мы все в редакции с величайшим интересом поджидаем получение от Вас полного текста. Ведь присланное Вами начало произвело на нас впечатление большой удачи, сулящей обогатить мемуарную литературу о Бунине трудом большого интереса и значения.

В своей архивно-документальной основе наш «бунинский том» уже сложился, осталось еще немного разного рода и авторских и редакторских работ.

Итак, позвольте просить Вас продолжить Вашу работу, получение которой, повторяю, мы поджидаем с большим интересом.

${ }^{27}$ Адамович написал Бахраху 26 июня 1968 г.:

Я получил письмо от Дубовикова из «Лит<ературного> насл<едства>». Он очень доволен началом моего Бунина - и ждет продолжения. Значит, делать нечего, надо написать и послать. Надеюсь, так поступите и Вы (пожалуйста!). Кстати, я, отвечая, сослался на Вас, т. е. что Вам дан срок - август, и что, значит, я тоже пришлю свое в августе. Они спешили, но, очевидно, задерживаются. Дубовиков, в ответ на мое заявление, что я не могу согласиться ни на какую правку без моего ведома, пишет «как Вы могли думать!?» - и обещает прислать корректуру [Письма Георгия Адамовича А. В. Бахраху (1966-1968), c. 185; приводится по оригиналу: BAR. Ms Coll Bacherac].

${ }^{28}$ Печатается по оригиналу (отпуск машинописи с исходящим номером: «№ 130»).

${ }^{29} 6$ сентября 1968 г. Адамович писал А. К. Бабореко:

Рад, что вам пришлись по душе первые мои страницы воспоминаний о Бунине. Я колеблюсь, продолжать ли их. Пожалуй, поздно, да есть и другие соображения. Впрочем, окончить их все равно следовало бы, где бы и когда бы они ни появились [Письма Георгия Адамовича, 1994а, с. 86]. 
С глубоким уважением
Член редколлегии «Литературного наследства»

С. Макашин

\section{2. Г. В. Адамович - С. А. Макашину ${ }^{30}$ \\ 27 сентября 1968 г. Париж}

Paris $8^{\mathrm{e}}$

7, rue Fréd<éric $>$ Bastiat

27 сент. 1968

Глубокоуважаемый Сергей Александрович

Благодарю Вас за письмо.

Если время еще есть, я пришлю Вам окончание моих воспоминаний о Бунине. Не могу точно назначить срок, т. к. сейчас я не совсем здоров, должен много лежать и заниматься только такой работой, которая необходима в целях практических.

Надеюсь, однако, не очень задержать присылку воспоминаний (скажем, в ближайшие месяц-два, - не позже).

Примите искренний привет и лучшие пожелания

Георгий Адамович

\section{3. Г. В. Адамович - С. А. Макашину ${ }^{31}$ \\ 29 сентября 1968 г. Париж}

Paris 8-e

7 , rue Fréd $<$ éric $>$ Bastiat

29 сент. 1968

Глубокоуважаемый Сергей Александрович

Писал Вам третьего дня, в ответ на Ваше письмо от 20 сентября. А сегодня подумал, что м. б. Вам пригодятся письма Бунина ${ }^{32}$, отобрал фотокопии некоторых из них - и посылаю Вам $^{33}$.

${ }^{30}$ Печатается по оригиналу (вверху письма помета другой рукой: «Вх. № 42. 2.IX.68 г.»).

31 Печатается по оригиналу (вверху письма помета другой рукой: «Вх. № 9. 18.III-69 г.»).

${ }^{32}$ Адамович прислал копии 17 писем Бунина 1944-1945 гг. В том они не вошли и в 1974 г. были переданы в РГАЛИ вместе с другими невключенными материалами. Писем было гораздо больше, хотя до наших дней дошли не все. Сохранившаяся переписка напечатана полностью (49 писем Г. В. Адамовича И. А. Бунину и 63 - В. Н. Буниной, 35 ответных, в общей сложности 147 посланий) [Переписка И. А. и В. Н. Буниных с Г. В. Адамовичем].

3310 октября 1968 г. Адамович написал А. К. Бабореко:

Я послал С. А. Макашину несколько фотокопий писем Бунина. Некоторые, по-моему, интересны.

Есть у меня и другие, но такие, которые для печати не годятся. А воспоминания свои о нем я допишу и пришлю, только не могу точно указать срок. Труд это не большой, но я сейчас очень занят и не совсем здоров. Оттого работаю медленнее, чем обычно. В сущности, я мог бы написать о Бунине сто страниц, но хорошо, если напишу хотя бы двадцать [Письма Георгия Адамовича, 1994a, с. 87].

Копии писем, однако, не были получены и полтора месяца спустя, о чем Бабореко сообщил Адамовичу, и тот ответил 26 ноября 1968 г.:

То, что фотокопии писем Бунина не дошли, меня огорчило - и удивило. Я послал их, конечно, заказным, расписка у меня сохранилась, и я мог бы вам ее прислать для справок на почте. Не знаю только, нужно ли это. Я знаю случаи (по личному опыту), когда посланное заказным возвращалось. 
«Некоторых» - потому, что в других попадаются или замечания и выражения, в печати невозможные, или обидные отзывы о людях еще живых. Если Вы решите эти письма опубликовать, то, вероятно, сочтете необходимым кое-что в них выбросить. Против этого я не возражаю, но прошу сделать указания, что такое-то письмо печатается с сокращениями (конечно, чем меньше сокращений, тем лучше! Есть два-три письма, которые Вы сократили бы почти целиком: это я понимаю и поэтому этих писем не присылаю). Кое-где, пожалуй, нужны примечания, т. е. разъяснение имен или фактов: я охотно это сделаю. Если же письма эти Вам вообще не нужны, будьте добры, не откажите вернуть мне фотокопии.

С искренним уважением

Георгий Адамович

P. S. Более ранние письма Б<унина > я - увы! - растерял. К этим, по моему, следовало бы дать указание - «Из писем за последние 10 лет жизни».

\title{
14. С. А. Макашин - Г. В. Адамовичу ${ }^{34}$ 11 октября 1968 г. Москва
}

11 октября 1968 г.

Глубокоуважаемый Георгий Викторович!

Благодарю Вас за ответ ${ }^{35}$ на мое письмо, который всех нас в редакции весьма обрадовал.

Итак, мы будем терпеливо ожидать окончания Ваших столь ценных воспоминаний о Бунине и присылки их нам.

С уважением и лучшими пожеланиями

С. Макашин

\author{
15. С. А. Макашин - Г. В. Адамовичу ${ }^{36}$ \\ 10 декабря 1968 г. Москва
}

10 декабря 1968 г.

Глубокоуважаемый Георгий Викторович!

Спешу сообщить Вам, что «пропавшая грамота» ${ }^{37}$ объявилась. Как оказывается, пакет с посланными Вами фотокопиями писем И. А. Бунина попал в Библиотеку Института мировой литературы Академии Наук, чьим органом является наше «Литературное на-

Но не думаю, чтобы письмо могло бесследно пропасть. Других копий у меня нет, а письма давно уже находятся в одном из далеких университетов, куда я их сдал на хранение. Просить вторично сделать фотокопии я не могу. Должен добавить, что я отобрал для «Литературного наследства» те письма, на которые, по-моему, не может по их содержанию возникнуть никаких возражений. Все это меня смущает, и если я задерживаю окончание своих воспоминаний о Бунине, то в силу того же смущения. Не уверен, что писать их стоит, - хотя и в них тоже нет, не было и не будет ничего, могущего вызвать возражения [Письма Георгия Адамовича, 1994a, с. 87].

${ }^{34}$ Печатается по оригиналу (отпуск машинописи с исходящим номером: «№ 144»).

35 Имеется в виду письмо 12 от 27 сентября 1968 г.

36 Печатается по оригиналу (машинопись на бланке «Литературного наследства» с исходящим номером: «№ 170», подписью-автографом, исправлениями от руки и пометой в правом верхнем углу: «Копия»).

${ }^{37}$ Речь о копиях писем Бунина, см. п. 13. «Пропавшая грамота» - название повести (1829-1831) Н. В. Гоголя. 
следство». По неопытности или по нерадивости молодого сотрудника информация об этом пакете поступила к нам лишь вчера ${ }^{38}$. Очень это плохо, конечно. Но все же хорошо все то, что хорошо кончается. Сейчас мы отдаем письма в переписку на машинку.

Очень надеемся, что Вы продолжаете работу над столь удачно начатыми воспоминаниями, и с нетерпением ожидаем их продолжение.

Еели я поеду в ближайшие дпи в Нариж поетараюеь увидетьеяе Вами. Еелиженет, то Позвольте воспользоваться этим письмом и передать Вам мои новогодние поздравления, а с ними и лучшие пожелания.

\section{С уважением}

Ваш

С. Макашин

\section{6. С. А. Макашин - Г. В. Адамовичу ${ }^{39}$ \\ 18 марта 1969 2. Москва}

18 марта 1969 г.

Многоуважаемый Георгий Викторович!

По обстоятельствам, с огромным опозданием отвечаю на Ваше последнее письмо ${ }^{40}$, за что и приношу Вам свои глубочайшие извинения.

Напомню, что я получил посланные Вами фотокопии писем Бунина за несколько дней до своего отъезда во Францию. Отправляясь туда с целью несколько отдохнуть от напряженной работы, связанной с Тургеневским юбилеем ${ }^{41}$ (я был заместителем председателя Всесоюзного юбилейного комитета), я намеревался, вместе с тем, посетить в Париже всех участников и вкладчиков бунинского тома «Литературного наследства». К глубокому моему сожалению этих своих намерений я не смог осуществить, за единственным исключением - встречи с Л. Ф. Зуровым. Дело в том, что программа нашей поездки (я и жена ездили с небольшой группой писателей) задержала нас в Орлеане и Шартре, и на Париж осталось совсем немного времени. Но главное в том, что в Париже я целиком ушел в тургеневские дела, также в те бумаги из архива Герцена, которые мы долго искали,

38 Объяснениям насчет «неопытности» и «нерадивости» Адамович не очень поверил и 20 декабря 1968 г. писал Бахраху:

$\mathrm{C}$ «Лит<ературным> наследством» у меня была переписка долгая. В сентябре я послал им (Макашину) 20, или даже больше, фотокопий писем Бунина. Выбрал те, где ничего нет политического - и их тогда же о высылке известил. С месяц назад Бабореко мне написал, что письма не дошли, что Макашин и Дубовиков крайне огорчены, и намекнул, что лучше было бы послать на частный адрес, хотя бы ему, т. е. Бабореке. Я ответил, что других фотокопий у меня нет, оригиналы в Йельском университете и ничего я им больше послать не могу. Добавил, что мне не хочется писать продолжение воспоминаний, т. к. может «не дойти» и это. Вчера получил письмо от Макашина, что фотокопии они наконец получили, что пакет «по недоразумению» был отправлен по другому адресу, а там кто-то его, тоже «по недоразумению», не сразу им передал. Конечно, он правду написать не может. Но все ясно и так. Ведь никакого «другого адреса» на конверте не было! Значит им (как мне писал Бабореко) не очень доверяют и они под надзором. Макашин просит непременно кончить воспоминания и им прислать. Я через месяц поеду в Ниццу, пожалуй, там напишу, но далеко не уверен, что они в «Л<итературное> н<аследство>» попадут. Ну, on verra <увидим - фр.>. Вы оказались аккуратнее меня, уже им все послали. А был от них ответ? [Письма Георгия Адамовича А. В. Бахраху (1966-1968), с. 190; приводится по оригиналу: BAR. Ms Coll Bacherac].

39 Печатается по оригиналу (отпуск машинописи с исходящим номером: «№ 45»).

${ }^{40}$ Речь о письме 13 от 29 сентября 1968 г.

${ }^{41}$ В 1968 г. широко отмечалось 150-летие со дня рождения И. С. Тургенева. 
и которые теперь, после смерти А. Ф. Родичевой ${ }^{4}$, оказались в Национальной библиотеке. В недалеком прошлом я был редактором 4-х обширных томов «Лит. наследства» ${ }^{43}$, в которых мы обнародовали много сотен документов из огромного зарубежного архива Герцена и Огарева, некогда единого, но давно распавшегося на много частей. Кроме того, я был одним из редакторов не столь давно завершенного академического Собрания сочинений и писем Герцена в 30-ти томах. Все это пишу Вам, чтобы объяснить, почему в Париже мне пришлось в первую очередь потратить время на Тургенева и Герцена, а не на Бунина, хотя мне очень хотелось встретиться и с Вами, и с Б. К. Зайцевым, С. Ю. Прегель и Н. В. Кодрянской ${ }^{44}$.

А теперь о присланных Вами письмах Бунина. Среди них есть ряд весьма интересных, и мы их, конечно, напечатаем. Если текст письма мы будем публиковать не полностью, то это обязательно найдет отражение в заглавии: Из письма от такого-то числа и месяца. Какие на пояснение комментарии понадобятся, я сообщу позже. Количество и объем необходимых примечаний, на мой взгляд, будут невелики.

Вы просите возвратить фотокопии тех писем, которые, возможно, не понадобятся нам для публикации. Конечно, мы готовы и обязаны исполнить Вашу просьбу. Но не согласились бы Вы на передачу всех полученных нами от Вас фотокопий в Отдел рукописей Государственной библиотеки СССР им. В. Ленина? Мы передаем туда, на постоянное хранение, все рукописи и письма Бунина, которые поступают к нам в ходе нашей работы - в подлинниках или в фотокопиях. Разумеется, решение этого вопроса всецело зависит от Вас.

А. Н. Дубовиков и я, как и все другие участники бунинского тома, с величайшим нетерпением продолжаем ожидать продолжение Ваших замечательных воспоминаний о Бунине. Надеемся, что пребывание на юге принесло пользу Вашему здоровью и что вскоре мы получим от Вас рукопись ${ }^{45}$.

Будьте здоровы и благополучны

С уважением

С. Макашин

\footnotetext{
${ }_{42}$ Родичева Александра Федоровна (1883-?) - дочь Ф. И. Родичева, переписывавшегося с Огаревым, подруга Н. А. Герцен, у которой хранилась часть архива А. И. Герцена. С 1919 г. в эмиграции во Франции. В качестве даты ее смерти везде указывают 1971 г., что, судя по данному письму, неверно, см.: [Незабытые могилы, т. 6, ч. 1, с. 233; Российское зарубежье во Франции, т. 2, с. 622].

${ }^{43}$ Имеются в виду тома 61-63: «Герцен и Огарев» (М. : Изд-во АН СССР, 1953-1956) и том 64: «Герцен в заграничных коллекциях» (М. : Изд-во АН СССР, 1958).

442 января 1969 г. Адамович написал Бахраху:

Здесь был на днях Макашин, несколько дней (по делам Буживаля и Тургенева). Был у Зурова, а потом у Леонидова (антрепренера). Зуров будто бы произвел на него ужасающее впечатление, отчасти и как сумасшедший. Но мне Макашин не звонил, хотя Бабореко писал мне, как он, т. е. Б<абореко>, рад, что $\mathrm{M}<$ акашин> со мной увидится. Это в порядке вещей, т. к. Леонидову позвонили из посольства с вопросом, хочет ли и он Макашина принять и когда. Значит, его визиты были проконтролированы [Письма Георгия Адамовича А. В. Бахраху (1969-1972), с. 132; приводится по оригиналу: BAR. Ms Coll Bacherac].

4514 марта 1969 г. Адамович написал Бахраху:

Вы спрашиваете, как мои дела с «Лит<ературным> наследством». Я твердо обещал докончить свои мемуары в марте, но не уверен, что обещание сдержу. Вероятно, опоздаю. Хотя они (и больше всего Бабореко) и пишут мне, что ждут, жаждут, надеются, я больше чем на 50 \% сомневаюсь, что мое сочинение у них появится. Кстати, недавно в Москве был Ляля Полонский, был в «Л<итературном> насл<едстве>» и об этом им говорил, в ответ на что они что-то мычали [Там же, с. 139].
} 


\section{7. Г. В. Адамович - С. А. Макашину ${ }^{46}$ \\ 27 марта 1969 г. Париж}

Paris

27 марта 1969

Многоуважаемый Сергей Александрович

Благодарю Вас за письмо (от 18.III). Я искренне жалею, что мы с Вами не встретились во время Вашего недавнего пребывания в Париже. Но понимаю, что для отдельных встреч у Вас могло не быть достаточно времени.

Конечно, я не возражаю против того, чтобы Вы передали фотокопии писем Бунина в Государственную библиотеку СССР, на вечное хранение. Должен добавить, что переслал я Вам фотокопии не всех писем покойного И<вана $>$ А <лексеевича $>$, а только тех, которые, на мой взгляд, Вы могли бы частично или полностью перепечатать. Остались у меня фотокопии писем или совсем незначительных, или таких, которые для Вас, вероятно, были бы неприятными (отчасти и таких, где есть резкие отзывы о писателях еще живых). Может быть, со временем следовало бы все эти материалы передать в Гос. Библиотеку CCCP, не для печати, а для хранения. Так, по крайней мере, мне кажется.

Что же касается продолжения - или, вернее, окончания, - моих воспоминаний о Бунине, то простите за задержку. Я был все время занят неотложными делами, - неотложными потому, что необходимыми для существования. А писать две или три вещи сразу, попеременно, я и не люблю, и даже не способен. Надеюсь твердо прислать Вам окончание записок в ближайшие две-три-четыре недели, т. е. в течение апреля, - если не случится ничего непредвиденного.

Шлю сердечный привет и прошу передать лучшие пожелания А. Н. Дубовикову.

Преданный Вам

Г. Адамович

\section{8. С. А. Макашин - Г. В. Адамовичу ${ }^{47}$ \\ 11 апреля 1969 г. Москва}

11 апреля 1969 г.

Многоуважаемый Георгий Викторович!

Отвечаю на Ваше письмо от 27 марта.

Благодарю Вас за Ваше любезное согласие передать после их использования в нашем томе присланные Вами фотокопии писем Бунина на постоянное хранение в Государственную библиотеку СССР. Дирекция Отдела рукописей библиотеки с большой радостью и благодарностью готова принять материалы. Если Вы не возражаете, они будут переданы от Вашего имени, в качестве Вашего дара.

Разумеется, Отдел рукописей с полной готовностью принял бы от Вас на постоянное хранение и все другие письма Бунина, для публикации которых время еще не пришло. Вы могли бы обусловить эту передачу любыми требованиями не касаться этих писем до такого-то года или разрешить обращение к ним исключительно для исследовательских

${ }^{46}$ Печатается по оригиналу (вверху письма пометы разными почерками: «Отв.11.IV.69» и «Вх. № 35. 22.IX-69 г.»).

47 Печатается по оригиналу (отпуск машинописи с исходящим номером: «№ 65»). 
целей, а не для публикаций и т. д. Одним словом, весь этот вопрос и возможные варианты для решения всецело зависят от Вас.

Да, я и до сих пор полон сожаления, что не удалось нам повидаться в Париже.

Спасибо за оптимистическую информацию о Вашей работе над завершающей частью воспоминаний о Бунине. Ждем их с большим нетерпением.

А. Н. Дубовиков благодарит Вас за привет и в свою очередь кланяется Вам.

Будьте здоровы и благополучны

Ваш

С. Макашин

\section{9. Г. В. Адамович - С. А. Макашину ${ }^{48}$ \\ 14 апреля 1969 г. Париж}

Paris $8^{\mathrm{e}}$

7 , rue Fréd <éric $>$ Bastiat

14 апреля 1969

Глубокоуважаемый Сергей Александрович

Наконец «удосужился» написать окончание воспоминаний о Бунине.

Шлю сердечный привет

Ваш Г. Адамович

\section{0. С. А. Макашин - Г. В. Адамовичу ${ }^{49}$ \\ Конеи, апреля 1969 г. Москва}

Глубокоуважаемый Георгий Викторович,

Пакет от Вас получен. Только что прочитал присланное окончание Вашего мемуарного очерка и нахожусь под сильным впечатлением от прочитанного. Отличные воспоминания написали Вы, Георгий Викторович, отличные. Это даже не первый, а экстра-класс мемуарной прозы. Для меня как читателя важно и любопытно было убедиться, что то представление о Бунине, которое у меня могло сложиться только на основании его произведений и других письменных источников, оказывается, находится в соответствии с живым восприятием его личности людьми, хорошо его знавшими. Думаю, что таково будет ощущение и всех других читателей Вашего очерка.

Сейчас у меня нет никаких к Вам замечаний и просьб по тексту. Возможно, что при непосредственной подготовке рукописи возникнут какие-либо мелкие вопросы. Тогда я напишу Вам.

Еще одно: если у Вас возникнет желание дополнить написанное новым материалом или развить уже изложенное - милости просим.

С уважением и благодарностью

Ваш

(С. Макашин)

P. S. Нет, все же один «вопрос» набежал. Я только что говорил по телефону с вдовою К. Г. Паустовского Татьяной Алексеевной и спросил ее о письме Ивана Алексеевича.

\footnotetext{
48 Печатается по оригиналу (вверху письма помета другой рукой: «Вх. № 34. 22.IX-69»).

${ }^{49}$ Печатается по оригиналу (отпуск машинописи с пометой от руки: «Исх. № 72. 6.V.69 г.»).
} 
Письма она не помнит, но помнит, что Константин Георгиевич получил от Бунина большую телеграмму с похвалами рассказу «Корчма на Брагинке». По словам Татьяны Алексеевны, Паустовский не мог не ответить Бунину, хотя текста этого ответа она не может найти в бумагах К. Г. (машинописной копии). Телеграмму И. А. Бунина мы опубликуем в нашем томе. Нужно ли Вам менять в Вашем тексте «письмо» на «телеграмму», решите, пожалуйста, сами.

\section{1. Г. В. Адамович - С. А. Макашину ${ }^{50}$ \\ 6 мая 1969 г. Париж}

Paris

6 мая 1969

Глубокоуважаемый Сергей Александрович

Получил сегодня Ваше письмо. Спасибо. Очень рад, что мои воспоминания о Бунине пришлись Вам по душе.

Два слова по поводу письма Паустовскому.

Несколько лет тому назад Паустовский был в Париже, и я с ним встретился. Вот его дословный - или приблизительно дословный - рассказ:

Было это до 1953 года. Он узнал, что в Союзе Писателей получено письмо Бунина на его имя и пошел туда за ним. Ему сказали, что письмо находится у Фадеева. Он пошел к Фадееву. Тот передал ему письмо, уже распечатанным - и сказал:

- Имейте в виду, что отвечать ему вы не имеете права (или «не должны», «не можете» - но смысл тот же: не отвечайте!)

Паустовский ответить и не решился. Думаю, что телеграмма была потом. О ней я ничего не знаю. Меня удивляет, что Татьяна Алекс. Паустовская отрицает наличие письма: при нашем разговоре она присутствовала. Было это в Буживале, около Парижа, по приглашению наших общих друзей Кодрянских, устроивших встречу.

Мне кажется, что текст мой, со словом «письмо», а не «телеграмма», можно оставить таким, как он есть. Впрочем, если измените, я не возражаю: дело Ваше. А то, что я Вам сейчас написал - только к Вашему сведению, в виде объяснения и, конечно, не для печати.

Искренне Ваш

Г. Адамович

P. S. У меня создалось тогда впечатление, что Паустовский был очень огорчен тем, что не ответил Бунину. Это чувствовалось по тону его рассказа.

\section{2. С. А. Макашин - Г. В. Адамовичу ${ }^{51}$ 23 мая 1969 2. Москва}

23 мая 1969 г.

Глубокоуважаемый Георгий Викторович

Отвечаю на Ваше письмо от 6 мая.

\footnotetext{
${ }^{50}$ Печатается по оригиналу (вверху письма помета от руки: «Вх. № 33. 22.IX.69»).

51 Печатается по оригиналу (отпуск машинописи с исходящим номером «№ 84», исправлением опечаток от руки и пометой: «Г. В. Адамовичу»).
} 
Некоторые неясности в вопросе об обращении Бунина к Паустовскому, по поводу рассказа «Корчма на Брагинке», продолжаются. Оказывается, существует еще и открытка, которую Бунин послал Паустовскому на адрес издательства «Московский рабочий» (в этом издательстве вышла книга, в которой был напечатан названный рассказ). Открытка эта сохранилась у тогдашней жены Паустовского Валерии Владимировны Навашиной. Татьяна Алексеевна не знала об этой открытке. Очевидно, лишь тогда, когда у меня на столе будут лежать и открытка, и телеграмма Бунина, можно будет определить последовательность этих двух эпистолярных документов.

Будьте здоровы и благополучны

С уважением ваш

С. Макашин

P. S. Я только что вернулся из г. Кирова (бывш. Вятка), куда ездил на открытие мемориального музея Салтыкова-Щедрина (в доме, где прошли 8 лет его ссылки). После моего выступления мне был задан вопрос об отношении Бунина к Салтыкову. Я сообщил то, что знаю, но знаю-то я очень мало. Мне известны высокая оценка общественного значения Щедрина Буниным в его молодые годы (стихотворение и статья в газете «Орловский вестник» 1890, № 94) и отрицательный отзыв в одной беседе поздних лет, зафиксированный в «Грасском дневнике» Г. Н. Кузнецовой. Не знаете ли Вы чего-либо большего?

\section{3. А. Н. Дубовиков - Г. В. Адамовичу ${ }^{52}$ 30 июля 1970 г. Москва}

30 июля 1970 г.

Глубокоуважаемый Георгий Викторович!

Простите, что так давно не писал Вам - последний год был у меня очень трудным, особенно много времени и сил отнимал бунинский том. Материалов для него набралось гораздо больше, чем мы могли предполагать, когда приступали к работе. Вырос он почти вдвое и будет выпущен в двух книгах (как это было у нас раньше с некоторыми томами «Из парижского архива Тургенева», «Толстой и зарубежный мир» и др.).

В июле том (т. 84, «Иван Бунин») был утвержден редколлегией нашего издания, а затем и Ученым советом Института мировой литературы, органом которого является «Литературное наследство». Представленный нами том утвержден без изменений в его составе. Ваши воспоминания о Бунине идут полностью ${ }^{53}$, лишь с некоторыми мелкими

\footnotetext{
52 Печатается по оригиналу (машинописный отпуск с исходящим номером: «№ $130 »)$.

53 У Адамовича на этот счет были большие сомнения, о которых он написал Бахраху 28 октября 1969 г.: Меня интересует, имеете ли Вы сношения с «Лит<ературным> наследством». С моего горизонта они исчезли. Вот уже несколько месяцев - ни слова! Как это понять? Я думаю, что они печатать нас par le temps qui court <в настоящее время - фр.> не могут, но стесняются это сказать [Письма Георгия Адамовича А. В. Бахраху (1969-1972), с. 141; приводится по оригиналу: BAR. Ms Coll Bacherac].

Еще через несколько месяцев, 6 июля 1970 г., Адамович написал А. К. Бабореко:

У меня есть к вам просьба. По некоторым сведениям или слухам я далеко не уверен, что мои воспоминания о Бунине будут включены в «Литературное наследство». Если вы узнаете, что это в самом деле так, будьте добры, сообщите мне. Столетие со дня рождения Ивана Алексеевича совсем близко, а если записки мои не пройдут в «Литературном наследстве», мне хотелось бы распорядиться ими иначе (конечно, только в этом случае) [Письма Георгия Адамовича, 1994a, с. 88].
} 
исправлениями чисто редакционного характера - в гранках, которые мы Вам пришлем, Вы все это увидите.

Сейчас мы заняты окончательной подготовкой рукописи к печати и рассчитываем осенью отправить его в издательство (раньше не удастся из-за летних отпусков).

С. А. Макашин просит передать Вам его искренний привет. В ноябре у него намечается поездка в Париж, и он надеется повидаться с Вами, если Вы не будете в отъезде.

Будьте здоровы. Желаю Вам всего доброго

С глубоким уважением

(А. Н. Дубовиков)

\section{Источники}

Г. В. Адамович - Н. В. Кодрянской. 25 августа 1970 г. // РАЛ. MS 1408.

Г. В. Адамович - В. Д. Самарину. 29 августа 1969 г. // Beinecke Rare Book and Manuscript Library, Yale University. Vladimir Samarin papers. Gen MSS 295. Box 1. Folder 1.

Акт [о передаче в РГАЛИ материалов 84-го тома («Иван Бунин»)]. 31 января 1974 г. // ОР ИМЛИ. Ф. 575. № І. Д. 12.

А. Н. Дубовиков - А. В. Бахраху. 1 октября 1973 г. // ОР ИМЛИ. Ф. 575.

А. Н. Дубовиков - С. Ю. Прегель.17 апреля 1967 г. // ОР ИМЛИ. Ф. 575.

Макашин Сергей Александрович. Одиннадцатая беседа - 17 сентября 1987 года / запись, расшифровка и компьютерный набор М. В. Радзишевской // НБ МГУ. Кассета № 904.

С. Ю. Прегель - Г. В. Адамовичу // Sophie Pregel and Vadim Rudnev Collection. University of Illinois at Urbana-Champaign Archives. RS15/35/36. Box 4.

\section{Исследования}

Адамович Г. Литературные заметки // Русские новости. 1949. 29 июля. № 217. С. 4.

Адамовии Г. Советский Саводник // Новое русское слово. 1952. 21 декабря. № 14848. С. 8.

Адамович Г. Мракобесие // Новое русское слово. 1957. 19 мая. № 16031. С. 8.

Адамовии Г. О книгах и авторах: Заметки из литературного дневника. Париж, 1967.

Адамович Г. Книга А. Бабореко о Бунине // Русская мысль. 1968. 14 марта. № 2678. С. 4.

Адамовии Г. Бунин: Воспоминания // Новый журнал. 1971. № 105. С. 115-137.

Адамович Г. Бунин: Воспоминания // Знамя. 1988. № 4. С. 178-191.

Адамович Г. Одиночество и свобода / сост., предисл. и прим. В. Крейда. М. : Республика, 1996.

Бунин И. А. Речной трактир. Нью-Йорк : M. Zetlin [Grenich Printing Corp.], 1945.

Бунин И. А. О Чехове (Из писем Г. В. Адамовичу) // Опыты. 1956. № 6. С. 25-27.

«Если чудо вообще возможно за границей...»: Эпоха 1950-х годов в переписке русских литераторов-эмигрантов / сост., предисл. и прим. О. А. Коростелева. М. : Библиотека-фонд «Русское зарубежье» : Рус. путь, 2008.

Литературное наследство. Т. 78 : Советские писатели на фронтах Великой Отечественной войны : в 2 кн. / ред. А. Н. Дубовиков и Н. А. Трифонов. М. : Наука, 1966.

Литературное наследство. Т. 84 : Иван Бунин : в 2 кн. / ред. А. Н. Дубовиков и С. А. Макашин при участии Т. Г. Динесман. М. : Наука, 1973.

«Не будьте на меня в претензии...»: Письма Г. В. Адамовича М. В. Вишняку 1938-1968 гг. / публ. О. Коростелева // Vademecum. К 65-летию Лазаря Флейшмана. М. : Водолей, 2010. С. $418-435$.

Незабытые могилы. Российское зарубежье: некрологи 1917-1997 : в 6 т. / сост. В. Н. Чуваков. М. : Пашков дом, 1999-2007. 
Переписка И. А. и В. Н. Буниных с Г. В. Адамовичем (1926-1961) / публ. О. Коростелева и Р. Дэвиса // И. А. Бунин: Новые материалы. Вып. І. М. : Рус. путь, 2004. С. 8-164.

Письма И. А. Бунина к Г. В. Адамовичу / публ. проф. А. Звеерс // Новый журнал. 1973. № 110. С. 158-175.

Письма Георгия Адамовича / публ. и коммент. А. Бабореко // Русская провинция. 1994а. № 4 (12). C. $83-87$.

Письма Георгия Адамовича / публ. и примеч. В. Крейда // Новый журнал. 1994б. № 194. C. $257-319$.

Письма Георгия Адамовича А. В. Бахраху (1957-1965) / публ. В. Крейда // Новый журнал. 2001. № 225. С. $148-185$.

Письма Георгия Адамовича А. В. Бахраху (1966-1968) / публ. В. Крейда // Новый журнал. 2002. № 228. C. 151-191.

Письма Георгия Адамовича А. В. Бахраху (1969-1972) / публ. В. Крейда // Новый журнал. 2003. № 230. C. 130-155.

Российское зарубежье во Франции: 1919-2000 : биогр. словарь : в 3 т. / под ред. Л. Мнухина, М. Авриль, В. Лосской. М. : Наука : Дом-музей Марины Цветаевой, 2008-2010.

Указатель публикаций о «Литературном наследстве» : материалы к библиографии / сост. Е. Д. Лебедева и А. Ю. Галушкин при участии М. А. Фролова // «Литературное наследство» за 80 лет: Указатели к томам 1-103 за 1931-2011 годы / отв. ред. А. Ю. Галушкин. М. : ИМЛИ РАН, 2012. (Литературное наследство. Т. 104. Кн. 1). С. 349-406.

Статья поступила в редакцию 26.03.2017

\author{
Коростелев Олег Анатольевич \\ кандидат филологических наук, \\ заместитель директора по научной работе, \\ Институт мировой литературы \\ им. А. М. Горького РАН \\ 121069, Москва, ул. Поварская, 25а \\ E-mail: okorostelev@mail.ru
}

\author{
Korostelev, Oleg Anatolyevich \\ PhD (Philology), Deputy Director, \\ Gorky Institute of World Literature \\ of the Russian Academy of Sciences, \\ 25a, Povarskaya Str., 121069 Moscow, \\ Russia \\ Email: okorostelev@mail.ru
}

\section{"I HAD A LONG CORRESPONDENCE WITH LITNASLEDSTVO": ON THE STORY OF ADAMOVICH'S FAILED PARTICIPATION IN THE PREPARATION OF THE BUNIN LITNASLEDSTVO VOLUME}

This article considers one of the earliest attempts of Soviet editors to resume the relationship with emigrants during the thaw period. Letter interchange as well as any kind of interaction between Soviet editors and emigrant authors was extremely rare at the time. One of the first attempts to get émigré authors to cooperate was the Bunin volume of the Literaturnoye Nasledstvo (the famous Literary Heritage series), whose preparation began in the mid-1960s. While working on the volume in 1966, the Litnasledstvo editors asked Georgy Adamovich to write memoirs about Ivan Bunin. Their correspondence lasted for several years (1966-1970), and the memoirs were finally written, but the thaw period had also come to an end, and, consequently, the publication was impeded by the Soviet censorship. The return of Bunin and émigré literature to Soviet Russia was only partially successful at the time. 
This article is accompanied by an appendix containing all the extant correspondence of Georgy Adamovich with the editors of the Bunin volume: it was preserved in the editorial archive of the Literaturnoye Nasledstvo and is now kept in the Department of Manuscripts of the Gorky Institute of World Literature (OR IMLI, F. 575).

Ke y w ords: G. V. Adamovich; I. A. Bunin; A. K. Baboreko; S. A. Makashin; Literaturnoye Nasledstvo; Russian emigration; memoirs; thaw.

\section{Acknowledgements}

The work is sponsored by the Russian Foundation for Basic Research, project 15-04-00297a "Literaturnoye Nasledstvo: A School of Thought and an Academic Series in the History of the National Literary Criticism of the $1930 \mathrm{~s}-80 \mathrm{~s}$ ".

Adamovich, G. (1949, July 29). Literaturnye zametki [Literary Notes]. Russkie novosti, 217, p. 4. (In Russian)

Adamovich, G. (1952, December 21). Sovetskii Savodnik [Soviet Savodnik]. Novoe russkoe slovo, 14848, p. 8. (In Russian)

Adamovich, G. (1957, May 19). Mrakobesie [Obscurantism]. Novoe russkoe slovo, 16031, p. 8. (In Russian)

Adamovich, G. (1967). O knigakh i avtorakh: Zametki iz literaturnogo dnevnika [On Books and Authors: Notes from a Literary Diary]. Paris. (In Russian)

Adamovich, G. (1968, March 14). Kniga A. Baboreko o Bunine [A. Baboreko's Book on Bunin]. Russkaia mysl', 2678, p. 4. (In Russian)

Adamovich, G. (1971). Bunin: Vospominaniia [Bunin: Memoirs]. Novyi zhurnal, 105, 115-137. (In Russian)

Adamovich, G. (1988). Bunin: Vospominaniia [Bunin: Memoirs]. Znamia, 4, 178-191. (In Russian) Adamovich, G. (1996). Odinochestvo i svoboda [Loneliness and Freedom]. Moscow: Respublika. (In Russian)

Baboreko, A. (Ed.). (1994). Pis'ma Georgiia Adamovicha [Letters from Georgy Adamovich]. Russkaia provintsiia, 4 (12), 83-87. (In Russian)

Bunin, I. (1945). Rechnoi traktir [River Inn]. New York: M. Zetlin [Grenich Printing Corp.]. (In Russian)

Bunin, I. (1956). O Chekhove (Iz pisem G. V. Adamovichu) [About Chekhov (From Letters to G. V. Adamovich)]. Opyty, 6, 25-27. (In Russian)

Chuvakov, V. (Ed.). (1999-2007). Nezabytye mogily. Rossiiskoe zarubezh'e: nekrologi 1917-1997 [Unforgotten Graves. Russian Abroad: Obituaries of 1917-1997] (Vols. 1-6). Moscow: Pashkov dom. (In Russian)

Dubovikov, A., \& Makashin, S. (Eds.). (1973). Literaturnoye nasledstvo (Vol. 84: Ivan Bunin (Books 1-2)). Moscow: Nauka. (In Russian)

Dubovikov, A., \& Trifonov, N. (Eds.). (1966). Literaturnoye nasledstvo (Vol. 78: Sovetskie pisateli na frontakh Velikoi Otechestvennoi voiny [Soviet Writers on the Fronts of the Great Patriotic War] (Books 1-2)). Moscow: Nauka. (In Russian)

Galushkin, A. (Ed.). (2012). Ukazatel' publikatsii o «Literaturnom nasledstve»: Materialy k bibliografii [Index of Publications on Literaturnoye Nasledstvo: Materials for the Bibliography]. In «Literaturnoe nasledstvo» za 80 let: Ukazateli k tomam 1-103 za 1931-2011 gody [Literaturnoye Nasledstvo over 80 years: Indices to volumes 1-103 for 1931-2011] (pp. 349-406). Moscow: IMLI RAN. (In Russian)

Korostelev, O. (Ed.). (2008). «Esli chudo voobshche vozmozhno za granitsei...»: Epokha 1950-kh godov v perepiske russkikh literatorov-emigrantov ["If a Miracle is Possible Abroad at All...": The Era 
of the 1950s in the Correspondence of Russian Émigré Writers]. Moscow: Biblioteka-fond «Russkoe zarubezh'e»; Russkii put'. (In Russian)

Korostelev, O. (Ed.). (2010). «Ne bud'te na menia v pretenzii...»: Pis'ma G. V. Adamovicha M. V. Vishniaku 1938-1968 gg. ["Do not Have a Grudge against Me...": G. V. Adamovich's Letters to M. V. Vishnyak 1938-1968]. In Vademecum. K 65-letiiu Lazaria Fleishmana [Vademecum. For the $6^{\text {th }}$ Birthday of Lazar Fleischman] (pp. 418-435). Moscow: Vodolei. (In Russian)

Korostelev, O., \& Davies, R. (Eds.). (2004). Perepiska I. A. i V. N. Buninykh s G. V. Adamovichem (1926-1961) [Correspondence of I. A. and V. N. Bunin with G. V. Adamovich (1926-1961)]. In I. A. Bunin: Novye materialy [I. A. Bunin: New Materials] (Issue I, pp. 8-164). Moscow: Russkii put'. (In Russian)

Kreyd, V. (Ed.). (1994). Pis'ma Georgiia Adamovicha [Letters from Georgy Adamovich]. Novyi zhurnal, 194, 257-319. (In Russian)

Kreyd, V. (Ed.). (2001). Pis'ma Georgiia Adamovicha A. V. Bakhrakhu (1957-1965) [Letters from Georgy Adamovich to A. V. Bakhrakh (1957-1965)]. Novyi zhurnal, 225, 148-185. (In Russian)

Kreyd, V. (Ed.). (2002). Pis'ma Georgiia Adamovicha A. V. Bakhrakhu (1966-1968) [Letters from Georgy Adamovich to A. V. Bakhrakh (1966-1968)]. Novyi zhurnal, 228, 151-191. (In Russian)

Kreyd, V. (Ed.). (2003). Pis'ma Georgiia Adamovicha A. V. Bakhrakhu (1969-1972) [Letters from Georgy Adamovich to A. V. Bakhrakh (1969-1972)]. Novyi zhurnal, 230, 130-155. (In Russian)

Mnukhin, L., Avril', M., \& Losskaia, V. (Eds.). (2008-2010). Rossiiskoe zarubezh'e vo Frantsii: 1919-2000: Biograficheskii slovar' [The Russian Abroad in France: 1919-2000: Biographical Dictionary] (Vols. 1-3). Moscow: Nauka; Dom-muzei Mariny Tsvetaevoi. (In Russian)

Zveers, A. (Ed.). (1973). Pis'ma I. A. Bunina k G. V. Adamovichu [Letters from I. A. Bunin to G. V. Adamovich]. Novyi zhurnal, 110, 158-175. (In Russian) 